\title{
ANALISIS PENGARUH MOTIVASI DAN PENGAWASAN TERHADAP PENINGKATAN KINERJA KARYAWAN DI CV. BAHRUL MAGHFIROH KOTA MALANG
}

\author{
Oleh: \\ Bambang Septiawan dan Ahmad Mudasyir \\ (okbamz@gmail.com) \\ Universitas Islam Balitar Blitar
}

ABSTRAK

Motivasi dan pengawasan merupakan elemen penting dalam penigkatan kinerja karyawan. CV. Bahrul maghfiroh telah menerapkannya dan sudah diteliti kefeektifan penggunaan dua hal tersebut dalam jurnal ini. Penelitian ini menggunakan metode kuantitatif dengan system pengolahan SPSS serta termasuk deskriptif karena menjelaskan secara detail tentang variabel yang diteliti. Hasil enelitian ini menunjukkan adanya hubungan secara parsial maupun simultan antatra motowasi dan pengawasan terhaadap kinerja karyawan CV. Bahrul maghfiroh.

\section{ABSTRACT}

Monitoring and mitivation are the main elements for improving employees' performances. CV. Bahrul Maghfiroh has already applied those poins and it has been researched the influences of those factors in this journal. This journal used quantitative method by using SPSS tool as well as included descriptive because it explains about the variables detailly. The result of this journal proves that monitoring and motivation influenced partially dan simultaneously to the employees' performance.

\section{PENDAHULUAN}

Sumber daya manusia merupakan salah satu bagian penggerak dari perusahaan yang memiliki potensi berkembang dan secara aktif mendorong produktifitas dalam memenuhi tujuan perusahaan. Mengelola karyawan tidak hanya sekedar memberi diskripsi pekerjaan dan peraturan yang harus dipatuhi saja, tetapi perlu adanya hubungan yang sinergis antara perusahaan dengan karyawan untuk mencapai tujuan perusahaan.

Lebih lanjut lagi, Robbins (2008) menjelaskan manajemen sumber daya manusia adalah perencanaan, pengorganisasian, pengarahan dan pengawasan kegiatan-kegiatan pengadaan, pengembangan, pemberian kompensasi, pengintegrasian, pemeliharaan dan pelepasan sumber daya manusia agar tercapai berbagai tujuan individu, organisasi dan masyarakat. Untuk mencapai hubungan yang sinergis tersebut, perusahaan harus dapat memperhatikan pola kinerja karyawannya. Dengan diadakannya riset sumber daya manusia (karyawan) secara intens diharapkan perusahaan/instansi mendapat umpan balik guna perbaikan kinerja perusahaan/instansi.

Salah satu keberhasilan pimpinan didukung oleh kinerja karyawan. Dalam pekerjaan adanya peraturan, operasional dan administratif menjadi bagian 
konstruktif dalam menggerakan karyawan, tetapi dengan adanya dukungan motivasi, lingkungan nyaman dan kondusif dan pengarahan bimbingan pada karyawan akan mendukung pengawasan dan tercapainya kinerja yang lebih baik seiring dengan perkembangan manajemen dan tenaga kerja saat ini. Tentunya dalam upaya menciptakan sumber daya manusia dengan melihat sulitnya untuk selektif memilih tenaga kerja yang bervariasi, perusahaan akan mencari yang terbaik untuk sumber daya manusianya yang merupakan modal perusahaan yang utama. Maka karyawan merupakan modal utama yang harus diberdayakan dengan maksimal diikuti dengan pengembangan karyawan yang tepat.

Menurut Mathis dan Jackson (2001) faktor-faktor yang mempengaruhi karyawan yaitu: kemampuan mereka, motivasi, dukungan yang diterima, keberadaan pekerjaan yang mereka lakukan, dan hubungan mereka dengan organisasi. Mangkunegara (2005) menjabarkan faktor-faktor yang mempengaruhi kinerja adalah: individual characteristics (karakteristik individual), organizational charasteristic (karakteristik organisasi), dan work characteristics (karakteristik kerja). Lebih lanjut Gomes (2003) menjelaskan bahwa kinerja selain dipengaruhi oleh faktor lingkungan juga sangat tergantung dari karakteristik individu seperti kemampuan, pengetahuan, keterampilan, motivasi, norma dan nilai. Dalam kaitannya dengan konsep kinerja, terlihat bahwa karakteristik individu seperti kepribadian, umur dan jenis kelamin, tingkat pendidikan suku bangsa, keadaan sosial ekonomi, pengalaman terhadap keadaan yang lalu, akan menentukan perilaku kerja dan produktivitas kerja, baik individu maupun organisasi sehingga hal tersebut akan menimbulkan kepuasan bagi konsumen.

Berdasarkaan uraian di atas, penulis menjabarkan bahwa kinerja merupakan kualitas dan kuantitas dari suatu hasil kerja (output) individu maupun kelompok dalam suatu aktivitas tertentu yang diakibatkan oleh kemampuan alami atau kemampuan yang diperoleh dari proses belajar serta keinginan untuk berprestasi. Motivasi merupakan kondisi yang menggerakkan diri pegawai terarah untuk mencapai tujuan kerja. Sikap mental merupakan kondisi mental yang mendorong seseorang untuk berusaha mencapai potensi kerja secara maksimal.

Lutans (2005) motivasi diartikan sebagai sebuah proses yang dimulai dari adanya kekurangan baik seacara fisiologi maupun psikologi yang memunculkan prilaku atau dorongan yang diarahkan untuk mencapai sebuah tujuan spesifik atau insentif. Kemudian Robbin (2003) motivasi adalah keinginan untuk berusaha sekuat tenaga untuk mencapai tujuan organisasi yang dikondisikan atau ditentukan oleh kemampuan usaha untuk memenuhi suatu kebutuhan individu.

Untuk mendapatkan suatu hasil pekerjaan yang baik dan bermutu tinggi maka diperlukan pengawasan yang baik. Guntur (2005) mengatakan bahwa pengawasan adalah sebagai keseluruhan kegiatan membandingkan, mengukur apa yang sedang atau sudah dilaksanakan dengan rencana yang telah ditetapkan sebelumnya dengan kriteria, norma dan standar.

Pada setiap instansi pemerintah maupun swasta memerlukan pengawasan dari pihak manajer. Pengawasan ini dilakukan oleh manajer sebagai suatu usaha membandingkan apakah yang dilakukan sesuai dengan rencana yang ditetapkan. Hal ini berarti juga pengawasan merupakan tindakan atau kegiatan manajer yang 
mengusahakan agar pekerjaan terlaksana sesuai dengan rencana yang ditetapkan atau hasil kerja yang dikehendaki.

Selain itu, pengawasan juga merupakan hal yang sangat penting dalam setiap pekerjaan baik dalam instansi pemerintah maupun swasta. Sebab dengan adanya pengawasan yang baik maka sesuatu pekerjaan akan dapat berjalan lancar dan dapat menghasilkan suatu hasil kerja yang optimal. Semakin lancar kerja dan disertai pengawasan yang baik maka pekerjaan itu akan berhasil dengan baik. Dengan pengawasan yang baik akan mendorong pegawai lebih giat dalam bekerja dan menghasilkan kerja yang baik pula terlebih apabila menyelesaikan pekerjaannya dengan semangat yang baik.

Seorang pemimpin pasti menginginkan perusahaan yang dipimpinnya mencapai keberhasilan. Oleh sebab itu perusahaan akan mencari yang terbaik untuk sumber daya manusianya yang merupakan modal perusahaan yang utama. Maka karyawan merupakan modal utama yang harus diberdayakan dengan maksimal diikuti dengan pengembangan karyawan yang tepat. Peneliti mendapatkan kasus yang bisa merugikan perusahaan yang sedang peneliti teliti. Diantaranya kurangnya kesadaraan akan kedisiplinan dan kurangnya motivasi kerja guna membangun semangat kerja karyawan.

Dengan demikian, pengaruh motivasi dan pengawasan terhadap produktivitas kerja karyawan menjadi sangat penting untuk dibahas. Hal ini dimaksud untuk melihat apakah dengan diadakannya motivasi dan pengawasan maka dapat berpengaruh terhadap peningkatan produktivitas kerja pegawai pada instansi ini. Pada instansi ini perlu ditingkatkan motivasi dan pengawasan yang efektif sehingga disiplin atau etos kerja pegawai dapat ditingkatkan untuk memacu produktivitas kerja pegawai yang tinggi. Apabila ada motivasi dan pengawasan yang efektif dari manajer maka semangat kerja akan timbul dan para pegawai akan bekerja dengan rajin dengan disiplin yang tinggi dan bertanggung jawab sehingga produktivitas kerja dapat meningkat dengan sendirinya.

Tujuan dari penelitian ini dapat dibagi menjadi tiga bagian. Pertama untuk mengetahui hubungan motivasi dengan peningkatan kinerja karyawan di CV. Bahrul Maghfiroh. Kedua untuk mengetahui hubungan pengawasan dengan peningkatan kinerja karyawan di CV. Bahrul Maghfiroh. Terakhir, untuk mengetahui hubungan antara motivasi dan pengawasan terhadap peningkatan kinerja karyawan CV. Bahrul Maghfiroh.

\section{METODOLOGI PENELITIAN}

Penelitian ini merupakan penelitian deskriptif kuantitatif, data yang diperoleh dari sampel populasi penelitian dianalisis sesuai dengan metode statistik yang digunakan, kemudian diinterprestasikan. Populasi dalam penelitan adalah seluruh pegawai CV. Bahrul Maghfiroh Kota Malang. Adapun jumlah populasi yang akan dijadikan data penelitian adalah 88 orang. Populasi dalam penelitan adalah seluruh pegawai CV. Bahrul Maghfiroh Kota Malang dan sampelnya 36 orang .

Lokasi dari penelitian ini adalah di CV. Bahrul Maghfiroh yang beralamat di Perum Joyo Grand XIII/195 Merjosari, Kecamatan Lowokwaru, Kota Malang. Penelitian ini dilaksanakan dari bulan September 2016 sampai dengan bulan 
November 2016. Penelitian ini adalah untuk mengetahui pengaruh Pengaruh Motivasi dan Pengawasan terhadap Peningkatan Kinerja Karyawan di CV. Bahrul Maghfiroh Kota Malang.

Ada dua jenis data dalam penelitian ini, pertama data primer berupa hasil angket dan kusioner yang diolah. Kedua, data sekunder yang berupa observasi, dokumentasi dan wawancara tak terstruktur kepada karyawan CV. Bahrul Maghfiroh.

Teknis analisis data dalam penelitian ini ada beberapa tahap. Pertama, Uji Validitas dilakukan untuk mengukur sah/validnya suatu kuesioner. Apabila nilai $\mathrm{r}$ hitung lebih besar dari nilai $\mathrm{r}$ tabel dan nilai $\mathrm{r}$ positif dan signifikan, maka butir pertanyaan tersebut dikatakan valid. Kedua, Uji Reliabilitas merupakan uji kehandalan yang bertujuan untuk mengetahui seberapa jauh alat ukur tersebut dapat dipercaya. Uji Reliabilitas dilakukan dengan menggunakn Cronbach alpha. Suatu konstruk/variabel dikatakan reliabel jika memberikan nilai (alpha >0,60).

Selanjutnya dilakukan analisis uji regresi linear berganda Penggunaan analisis ini dengan alasan untuk mengetahui hubungan antara variabel bebas dengan variabel terikat, yaitu antara Motivasi $\left(\mathrm{X}_{1}\right)$ dan Pengawasan $\left(\mathrm{X}_{2}\right)$ terhadap peningkatan Kinerja Karyawan (Y) dengan menggunakan persamaan regresi dua predictor.

Kemudian melakukan uji simultan Uji ini bertujuan untuk mengetahui pengaruh semua variabel independen yaitu motivasi kerja dan pengawasan kerja yang terdapat didalam model secara bersama-sama (simultan) terhadap variabel dependen yaitu pengaruh peningkatan kinerja. Untuk membuktikan kebenaran hipotesis digunakan uji $\mathrm{F}$, yaitu untuk mengetahui sejauh mana variabel-variabel bebas yang digunakan mampu menjelaskan variabel terikatnya. Apabila dari perhitungan nilai $\mathrm{F}_{\text {hitung }}>\mathrm{F}_{\text {tabel }}$ pada taraf signifikan 5\%, maka dapat dikatakan bahwa variabel bebas dapat menerangkan variabel terikat secara serentak. Sebaliknya jika nilai $\mathrm{F}_{\text {hitung }}<\mathrm{F}_{\text {tabel }}$ pada taraf signifikan 5\%, maka dapat dikatakan bahwa variabel bebas tidak mampu menjelaskan variabel terikat.

Lebih dari itu, dilaksanakan uji parsial Untuk menguji kemaknaan koefisien parsial digunakan uji t. Apabila $t_{\text {hitung }}>t_{\text {tabel }}$ pada taraf signifikan 5\%, maka dapat dikatakan bahwa variabel bebas dapat menerangkan variabel terikat atau dengan kata lain ada pengaruh antara variabel bebas dengan variabel terikat. Sebaliknya apabila $t_{\text {hitung }}<t_{\text {tabel }}$ pada taraf signifikan $5 \%$, maka dapat dikatakan bahwa variabel bebas tidak dapat menjelaskan variabel terikatnya atau dengan kata lain tidak ada pengaruh antara variabel bebas dengan variabel terikat.

\section{HASIL DAN PEMBAHASAN}

Berdasarkan hasil uji validitas diketahui bahwa semua item penelitian pada variabel independen dan dependen memiliki $r_{\text {hitung }}>r_{\text {tabel }}(0,329)$ atau nilai signifikansinya lebih kecil dari taraf nyata 5\% sehingga disimpulkan bahwa semua item pertanyaan telah valid dan dapat dilakukan analisis selanjutnya.

Instrumen dikatakan reliabel, jika nilai alpha crobach sama dengan 0,6. Berdasarkan perhitungan diketahui bahwa nilai alpha crobach pada variabel independen dan dependen berada di atas 0,6 sehingga dapat disimpulkan bahwa variabel tersebut telah reliable dan dapat dilakukan analisis selanjutnya. 
Hasil perhitungan regresi linier berganda digunakan untuk memprediksi besarnya hubungan antara variabel dependen yaitu Kinerja Karyawan (Y) dengan variabel independen yaitu Motivasi Kerja (X1) dan Pengawasan Kerja (X2). Hasil perhitungan yang menggunakan program SPSS 21 tersebut dapat ditunjukkan pada tabel berikut ini:

Tabel 4.3.

Hasil Uji Regresi Linier Berganda

\begin{tabular}{|c|c|c|c|c|c|c|}
\hline & \multirow{2}{*}{ Model } & \multicolumn{2}{|c|}{$\begin{array}{c}\text { Unstandardized } \\
\text { Coefficients }\end{array}$} & \multirow{2}{*}{$\begin{array}{c}\begin{array}{c}\text { Standardized } \\
\text { Coefficients }\end{array} \\
\text { Beta }\end{array}$} & \multirow{2}{*}{$\mathrm{t}$} & \multirow{2}{*}{ Sig. } \\
\hline & & B & $\begin{array}{l}\text { Std. } \\
\text { Error }\end{array}$ & & & \\
\hline \multirow{3}{*}{1} & (Constant) & 9,954 & 2,405 & & 4,139 & 0,000 \\
\hline & X1 (Motivasi Kerja) & 0,260 & 0,115 & 0,352 & 2,250 & 0,031 \\
\hline & X2 (Pengawasan Kerja) & 0,278 & 0,120 & 0,363 & 2,324 & 0,026 \\
\hline
\end{tabular}

Sumber data diolah

Variabel dependen pada hasil uji regresi Berganda adalah Kinerja Karyawan (Y) sedangkan variabel independennya adalah Motivasi Kerja (X1) dan Pengawasan Kerja (X2). Model regresi berdasarkan hasil analisis adalah:

$$
\mathrm{Y}=\mathbf{9 , 9 5 4}+\mathbf{0 , 2 6 0} \mathrm{X1}+\mathbf{0 , 2 7 8} \times \mathbf{2}+\mathrm{e}
$$

Interpretasi model regresi di atas adalah sebagai berikut :

- $\quad \beta_{0}=9,954$

Kostanta dari persamaan regresi ini menunjukkan nilai sebesar 9,954 artinya ketika tidak terdapat kontribusi variabel Motivasi Kerja (X1) dan Pengawasan Kerja (X2) maka Kinerja Karyawan (Y) akan bernilai sebesar 9,954.

- $\quad \beta_{1}=0,260$

Koefisien regresi ini menunjukkan bahwa kontribusi yang diberikan apabila variabel Motivasi Kerja (X1) semakin baik, maka Kinerja Karyawan (Y) akan semakin baik. Koefisien Motivasi Kerja (X1) bernilai positif artinya setiap peningkatan Motivasi Kerja (X1) 1 satuan maka akan meningkatkan Kinerja Karyawan (Y) sebesar 0,260 dengan asumsi variabel lain konstan.

- $\quad \beta_{2}=0,278$

Koefisien regresi ini menunjukkan bahwa kontribusi yang diberikan apabila variabel Pengawasan Kerja (X2) semakin baik, maka Kinerja Karyawan (Y) akan semakin baik. Koefisien Pengawasan Kerja (X2) bernilai positif artinya setiap peningkatan Pengawasan Kerja (X2) 1 satuan maka akan meningkatkan Kinerja Karyawan (Y) sebesar 0,278 dengan asumsi variabel lain konstan.

Koefisien determinasi $\left(\mathrm{R}^{2}\right)$ pada intinya mengukur seberapa jauh kemampuan model dalam menerangkan variasi variabel dependen $(\mathrm{Y})$, sedangkan sisanya dijelaskan oleh variabel lain diluar model. Penenlitian ini menggunakan nilai $\mathrm{R}$ Square untuk mengevaluasi model regresi terbaik. Berdasarkan hasil analisis data diketahui nilai $\mathrm{R}$ Square sebesar 0,377 atau 37,7\%, Artinya variabel Kinerja Karyawan (Y) pada Konsumen dijelaskan sebesar 37,7\% oleh variabel Motivasi Kerja (X1) dan Pengawasan Kerja (X2). Sedangkan sisanya sebesar 
$62,3 \%$ dijelaskan oleh variabel lain di luar persamaan regresi atau yang tidak diteliti dalam penelitian ini.

Pada analisis regresi linier berganda, penentuan variabel bebas paling dominan yang mempengaruhi variabel terikat digunakan nilai Koefisien Beta (Beta Coefficient). Berdasarkan hasil analisis regresi terlihat bahwa variabel Pengawasan Kerja (X2) merupakan variabel dengan nilai koefisien beta tertinggi yaitu sebesar 0,363. Jadi dapat disimpulkan bahwa variabel yang paling dominan mempengaruhi variabel Kinerja Karyawan (Y) adalah variabel Pengawasan Kerja (X2).

Uji $\mathrm{F}$ digunakan untuk menunjukkan apakah semua variabel bebas yaitu Motivasi Kerja (X1) dan Pengawasan Kerja (X2) mempunyai pengaruh yang signifikan secara bersama-sama (simultan) terhadap variabel Kinerja Karyawan (Y). Pengujian hipotesis dilakukan dengan uji $\mathrm{F}$, dengan cara membandingkan nilai Fhitung hasil analisis regresi dengan nila $F_{\text {tabel }}$ pada taraf nyata $\alpha=0,05$.

Tabel 4.4. Hasil Uji Simultan (Uji F)

\begin{tabular}{|c|c|c|c|c|c|}
\hline Model & Sum of Squares & Df & Mean Square & F & Sig. \\
\hline Regression & 40,792 & 2 & 20,396 & 9,970 & 0,000 \\
Residual & 67,513 & 33 & 2,046 & & \\
Total & 108,306 & 35 & & & \\
\hline
\end{tabular}

Sumber data diolah

Berdasarkan hasil analisis, diperoleh nilai $\mathrm{F}_{\text {hitung }}$ sebesar 9,970 dengan nilai signifikansi sebesar 0,000 . Nilai $F_{\text {tabel }}$ dengan derajat bebas 2 dan 33 pada taraf nyata 5\% sebesar 3,285. Karena $F_{\text {hitung }}>F_{\text {tabel }}(9,970>3,285)$ dan nilai sig. $F$ $(0,000)$ lebih kecil dari $\alpha(0,05)$. Hal ini menunjukkan bahwa variabel Motivasi Kerja (X1) dan Pengawasan Kerja (X2) secara simultan memiliki pengaruh yang signifikan terhadap Kinerja Karyawan (Y).

Pengujian model regresi secara parsial digunakan untuk mengetahui apakah masing-masing variabel independen pembentuk model regresi secara individu memiliki pengaruh yang signifikan terhadap variabel dependen atau tidak. Variabel independen pembentuk model regresi dikatakan berpengaruh signifikan jika $t_{\text {hitung }}>t_{\text {tabel }}$ atau signifikan $<\alpha=0,05$. Pengujian model regresi secara parsial adalah sebagai berikut:

Tabel 4.5. Hasil Uji Parsial (Uji T)

\begin{tabular}{|c|c|c|c|c|c|}
\hline Variabel bebas & Beta & $t_{\text {hitung }}$ & Sig. $t$ & $t_{\text {tabel }}$ & Keterangan \\
\hline X1 (Motivasi Kerja) & 0,352 & 2,250 & 0,031 & 2,035 & Signifikan \\
X2 (Pengawasan Kerja) & 0,363 & 2,324 & 0,026 & 2,035 & Signifikan \\
\hline
\end{tabular}

Sumber data diolah

Berdasarkan tabel di atas, pada variabel Motivasi Kerja (X1) diperoleh $t_{\text {hitung }}$ sebesar 2,250 dengan signifikansi sebesar 0,031. Nilai $t_{\text {tabel }}$ pada derajat bebas 33 dan taraf nyata 5\% sebesar 2,035. Karena nilai statistik uji $\left|t_{\text {hitung }}\right|>t_{\text {tabel }}$ $(2,250>2,035)$ atau nilai signifikansi $<0,05$ maka disimpulkan Motivasi Kerja (X1) secara parsial memberikan pengaruh yang signifikan terhadap variabel Kinerja Karyawan (Y). koefisien Motivasi Kerja (X1) yang positif menunjukkan bahwa apabila Motivasi Kerja (X1) semakin meningkat maka Kinerja Karyawan 
(Y) juga akan meningkat, sebaliknya semakin menurun Motivasi Kerja (X1) maka Kinerja Karyawan (Y) juga akan menurun.

Pada variabel Pengawasan Kerja (X2) diperoleh $t_{\text {hitung }}$ sebesar 2,324 dengan signifikansi sebesar 0,026 . Nilai $t_{\text {tabel }}$ pada derajat bebas 33 dan taraf nyata $5 \%$ sebesar 2,035. Karena nilai statistik uji $\left|t_{\text {hitung }}\right|>t_{\text {tabel }}(2,324>2,035)$ atau nilai signifikansi $<0,05$ maka disimpulkan Pengawasan Kerja (X2) secara parsial memberikan pengaruh yang signifikan terhadap variabel Kinerja Karyawan (Y). koefisien Pengawasan Kerja (X2) yang positif menunjukkan bahwa apabila Pengawasan Kerja (X2) semakin meningkat maka Kinerja Karyawan (Y) juga akan meningkat, sebaliknya semakin menurun Pengawasan Kerja (X2) maka Kinerja Karyawan (Y) juga akan menurun.

Kinerja tanpa adanya motivasi tidak akan mampu berjalan sesuai dengan standart yang ditetapkan. Telah banyak penelitian yang dilakukan jika motivasi merupakan salah satu jalan efektif untuk meningkatkan karyawan. Pemberian motivasi menurut Robbins (2008) dapat dilakukan dengan beberapa cara diantaranya pemberian reward. Pada CV. Bahrul Maghfiroh pemberian reward sudah dilaksanakan, namun hal tersebut masih dilakukan secara tidak terstruktur atau kondisional. Harusnya dilakukan secara rutin agar mampu meningkatkan semangat karyawan dalam hal bekerja. Contohnya diadakan bonus bulanan kepada karyawan yang prestasinya terbaik ditiap bulan.

Walaupun demikian motivasi saja tanpa diimbangi pengawasan akan menimbulkan dampak yang tidak sehat dan iklim kerja yang krang kondusif. Hersley (2003) menjabarkan mengukur, menilai, dan mengoreksi seperlunya diperlukan agar apa yang dikerjakan karyawan berjalan sesuai dengan aturan yang ada untuk mencapai tujuan perusahaan. Pengawasan di CV. Bahrul maghfiroh sudah dilakukan dengan baik secara rutin dilakukan, contohnya dengan diadakan rapat evaluasi rutinan dan sidak dari pemimpin $\mathrm{CV}$ untuk memastikan kinerja karyawan berjalan dengan baik.

Jika dua variabel tersenut dapat bersinergi dengan baik serta diterapkan secara berlanjut dalam CV. Bahrul Maghfiroh, maka kinerja karyawan akan meningkat dan mampu membawa keuntungan terhadap perusahaan. Tetapi, faktor-faktor lain juga harus dipertimbangkan untuk kemajuan perusahaan ini.

\section{KESIMPULAN DAN SARAN}

Dari hasil analisis data yang telah diperoleh, maka dapat ditarik kesimpulan sebagai berikut:

Pertama, dalam hasil penelitian ini diperoleh bahwa Motivasi Kerja (X1) secara parsial memberikan pengaruh yang signifikan terhadap variabel Kinerja Karyawan (Y). koefisien Motivasi Kerja (X1) yang positif menunjukkan bahwa apabila Motivasi Kerja (X1) semakin meningkat maka Kinerja Karyawan (Y) juga akan meningkat, sebaliknya semakin menurun Motivasi Kerja (X1) maka Kinerja Karyawan (Y) juga akan menurun.

Kedua, dalam hasil penelitian ini diperoleh bahwa Pengawasan Kerja (X2) secara parsial memberikan pengaruh yang signifikan terhadap variabel Kinerja Karyawan (Y). Koefisien Pengawasan Kerja (X2) yang positif menunjukkan bahwa apabila Pengawasan Kerja (X2) semakin meningkat maka Kinerja 
Karyawan (Y) juga akan meningkat, sebaliknya semakin menurun Pengawasan Kerja (X2) maka Kinerja Karyawan (Y) juga akan menurun.

Ketiga, Berdasarkan hasil penelitian dapat dilihat bahwa semua variabel bebas yaitu Motivasi Kerja (X1) dan Pengawasan Kerja (X2) mempunyai pengaruh yang signifikan secara bersama-sama (simultan) terhadap variabel Kinerja Karyawan (Y).

Hasil penelitian ini menunjukkan bahwa motivasi kerja dan pengawasan kerja secara signifikan mempengaruhi kinerja karyawan di CV Bahrul Maghfiroh Malang baik secara parsial maupun simultan. Terkait dengan hasil penelitian ini maka kinerja karyawan dapat ditingkatkan dengan memberikan motivasi kerja dan pengawasan kerja yang tinggi untuk mendorong kemampuan meraka dalam merencanakan, melaksanakan, dan mengevaluasi kinerja yang berlaku di perusahaan sehingga memperoleh hasil kerja yang maksimal.

Meningkatnya kinerja karyawan bukan semata-mata tugas dari atasan maupun karyawan itu sendiri, melainkan tugas bersama. Untuk itu diberikan saran untuk:

a. Direktur

Sebaiknya lebih mengidentifikasi, memotivikasi dan mengevaluasi karyawan dalam bekerja. Hal tersebut dapat dilakukan dengan memberikan penghargaan bagi karyawan yang berprestasi, memberikan kompensasi yang memadai, menciptakan kondisi kerja yang kondusif dan memberikan kesempatan bagi karyawan untuk maju.

Sebaiknya bisa menghargai karyawannya dengan memberikan semacam penghargaan, Penghargaan tersebut bisa berupa material ( Bonus,hadiah ) dan berupa non material ( pujian, pengakuan, peningkatan jabatan ) untuk lebih meningkatkan motivasi kerja dan pengawasan kerja terhadap kinerja guru.

b. Karyawan

Sebaiknya bisa meningkatkan pengetahuan, kemampuan,dan keterampilan dalam bekerja seperti dapat menggunakan media atau berdasarkan pengalaman langsung maupun tidak langsung yang sesuai dengan bidang masing-masing serta menjadi rekan kerja yang bersahabat saling mendukung dan mendorong antar rekan- rekannya untuk maju.

c. Pembaca

Bagi pembaca yang akan melakukan penelitian dibidang yang sama, jika menggunakan jurnal ini sebagai referensi, maka kiranya perlu dikaji kembali. Karena tidak menutup kemungkinan ada pernyataan yang belum sesuai, karena saya sebagai penulis merasa masih banyak kekurangan dan keterbatasan dalam menyelesaikan jurnal ini.

\section{Dafftar Pustaka}

Gomes, Faustino C. 2003. Manajemen Sumber Daya Manusia. Edisi kedua, Yogyakarta: Andi Offset. 
Guntur, Muhammad dkk. 2005. Pengantar Ilmu Administrasi dan Manajemen.s Makassar: FEIS UNM.

Hasley, D. George. 2003. Bagaimana Memimpin dan Mengawasi Pegawai Anda. Jakarta: PT. Rineka Cipta.

Luthans, F. 2005. Organizational Behavior. New York: McGraw-hill.

Mangkunegara, Anwar Prabu. 2005. Evaluasi Kinerja. Bandung: Refika Aditama

Manullang, M. 2005. Dasar-Dasar Manajemen. Yogyakarta : UGM University Press.

Mathis, R.L. \& J.H. Jackson. 2006. Human Resource Management: Manajemen Sumber Daya Manusia. Terjemahan Dian Angelia. Jakarta: Salemba Empat.

Moleong, Lexy J. 1991. Metode Penelitian Kualitatif. Bandung: Remaja Rosda Karya.

Robbbins dan Judge. 2007. Perilaku Organisasi, Buku 1 dan 2. Jakarta : Salemba Empat.

Robbins, Stephen P. 2008. Perilaku Organisasi. PT. Indeks Kelompok Gramedia.

Robins. 2003. Prilaku Organisasi.Jilid I.Jakarta: Prenhalindo. 